University of Nebraska - Lincoln

DigitalCommons@University of Nebraska - Lincoln

Nebraska Cooperative Fish \& Wildlife Research Nebraska Cooperative Fish \& Wildlife Research Unit -- Staff Publications

Unit

2012

\title{
The feasibility of switchgrass for biofuel production
}

\author{
Rob Mitchell \\ USDA Central-East Regional Biomass Center, rob.mitchell@ars.usda.gov \\ Kenneth P. Vogel \\ USDA Central-East Regional Biomass Center, kvogel1@unl.edu \\ Daniel R. Uden \\ University of Nebraska-Lincoln, danielruden87@gmail.com
}

Follow this and additional works at: https://digitalcommons.unl.edu/ncfwrustaff

Part of the Aquaculture and Fisheries Commons, Environmental Indicators and Impact Assessment Commons, Environmental Monitoring Commons, Natural Resource Economics Commons, Natural Resources and Conservation Commons, and the Water Resource Management Commons

Mitchell, Rob; Vogel, Kenneth P.; and Uden, Daniel R., "The feasibility of switchgrass for biofuel production" (2012). Nebraska Cooperative Fish \& Wildlife Research Unit -- Staff Publications. 169.

https://digitalcommons.unl.edu/ncfwrustaff/169

This Article is brought to you for free and open access by the Nebraska Cooperative Fish \& Wildlife Research Unit at DigitalCommons@University of Nebraska - Lincoln. It has been accepted for inclusion in Nebraska Cooperative Fish \& Wildlife Research Unit -- Staff Publications by an authorized administrator of DigitalCommons@University of Nebraska - Lincoln. 


\title{
The feasibility of switchgrass for biofuel production
}

Biofuels (2012) 3(1), 47-59

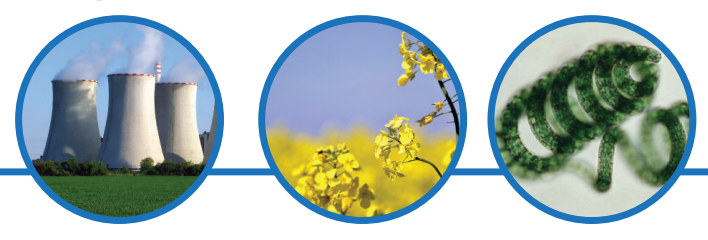

\begin{abstract}
Rob Mitchell*1, Kenneth P Vogel' \& Daniel R Uden²
Switchgrass research has been conducted cooperatively by the US Department of Agriculture and the University of Nebraska since the mid-1930s, with a primary focus on bioenergy since 1990 at several institutions. Progress has been made in switchgrass breeding and genetics, molecular genetics, establishment, fertility management, production economics, production energetics, harvest and storage management, ecosystem services and ethanol yield. A complete field-validated biomass production system has been developed for the Midwest and Central Plains. Even with favorable economic and sustainability results from field trials, switchgrass for bioenergy has not been adopted on a large scale. Lack of adoption is likely due to lower than needed efficiencies for conversion technologies, farmers not wanting to plant switchgrass without a viable bioenergy market and biorefineries not wanting to build without a viable long-term feedstock supply already in place. Answers to 22 of the most pressing questions concerning the feasibility of growing and supplying switchgrass to the biorefinery are provided based on research completed to date. Production, economic, net energy and sustainability research completed to date fully supports the use of switchgrass as a biomass energy crop.
\end{abstract}

Switchgrass (Panicum virgatum L.) is a perennial plant native to North America that is well adapted to marginally productive cropland similar to land enrolled in the Conservation Reserve Program (CRP). Switchgrass does not require annual establishment, requires fewer chemical inputs (pesticide and fertilizer) than traditional row crops, produces large quantities of biomass and provides important ecosystem services. However, switchgrass requires some level of input to optimize productivity and maintain stand quality. Several recent reviews have been conducted on switchgrass as a biomass feedstock [1-6].

In the 2011 Renewable Fuel Standards, commonly referred to as RFS2, the US EPA established 2011 volume requirements of 25 million 1 for cellulosic ethanol, 3 billion 1 for biomass-based diesel, 5.1 billion 1 for advanced biofuel and 52.8 billion 1 for renewable biofuel [101]. These volume requirements will continue to increase through to 2022 . With the exception of the
52.8 billion 1 for renewable biofuel (mostly ethanol from maize [Zea mays L.] grain), the technology for reaching these standards is not mature and the path to expanding beyond these standards, especially for cellulosic ethanol, is unclear.

A major impediment to the adoption of biomass energy production is the concern for the timely and long-term availability of biomass to the biorefinery. Specific questions for switchgrass include the amount of land area that must be planted to switchgrass to meet the demands of the biorefineries, how soon switchgrass can be supplied for a single biorefinery and for multiple biorefineries, the ability of seed producers to supply adequate amounts of seed to farmers, the ability of farmers to produce and deliver biomass to the biorefinery in a timely manner, as well as continuing questions on economics, storage, transportation and conversion. Fortunately, answers are now available to many of these questions for switchgrass in the Midwest

'Department of Agronomy \& Horticulture, USDA Central-East Regional Biomass Center, Grain, Forage \& Bioenergy Research Unit, USDA-ARS, Lincoln, NE 68583-0737, USA

${ }^{2}$ Nebraska Cooperative Fish \& Wildlife Research Unit-USGS, University of Nebraska, Lincoln, NE 68583, USA 


\section{Key terms}

Feedstock: Bulk raw material input into the bioreactor

Certified seed: Seed typically produced from foundation seed that is inspected by a certifying agency to maintain varietal purity. Seed produced from certified seed fields is used by farmers to grow the desired crop. and Great Plains based on research completed during the last 20 years. This research has included work on breeding and genetics $[1,6,7]$, ethanol potential [8], establishment [9-11], field-scale production economics [12], weed control [13], harvest and fertility management $[14,15]$, documentation of the value of ecosystem services [16,17], energy balance [18] and entomology [19], as well as compiling best management practices for establishment and management [102]. This research has demonstrated clearly that switchgrass for bioenergy is productive, protective of the environment and profitable for the farmer. Even with the availability of a complete production package for the central Great Plains, switchgrass for bioenergy production has not been adopted on a large scale. This lack of adoption is likely due to lower than needed efficiencies for conversion technologies, reduced investment due to the current economic climate, farmers not wanting to plant switchgrass without a viable bioenergy market and investors not wanting to build a biorefinery without a viable long-term feedstock supply.

Our purpose in this report is to provide researchbased information on the feasibility of growing and supplying switchgrass to the biorefineries for the production of liquid fuels in the Great Plains and Midwest USA. Additionally, similar research has been conducted in other agroecoregions or these research results are transferrable to those regions. Biofuel conversion platforms including biochemical or cellulosic fermentation and thermochemical platforms have advantages and disadvantages, but many of the feedstock production and logistic issues are independent of the conversion platform. We will use a question and answer format, drawing on questions asked by farmers and the bioenergy industry, to address the feasibility and production challenges of using switchgrass for bioenergy, emphasizing the central Great Plains and Midwest USA.

\section{Is switchgrass a new crop?}

Switchgrass is not a new crop. Switchgrass is native to most of North America east of the Rocky Mountains and extends north to $55^{\circ} \mathrm{N}$ latitude in northeastern Canada [20]. The US Department of Agriculture location in Lincoln, Nebraska, has been working with switchgrass continually since 1936. Initial research was for livestock, but for more than 20 years research has emphasized bioenergy [1]. Switchgrass has been used for pastures, wildlife plantings and other conservation purposes for more than 70 years [6], and was a major component of millions of hectares of CRP plantings. Bioenergy research on switchgrass has been conducted in most agroecoregions of the eastern half of the USA [14,21-26], as well as in Europe [27]. Although switchgrass is not a one-size-fits-all bioenergy feedstock and the volume of research and practical experience pales in comparison to traditional crops, switchgrass is the most advanced herbaceous perennial feedstock.

Where can switchgrass be productively grown in rainfed conditions?

Switchgrass will be productive anywhere rainfed maize is productive, but especially east of the 100th meridian $[6,102]$ and will be productive on sites not sustainably productive for maize. As with maize, switchgrass has the $\mathrm{C}_{4}$ photosynthetic pathway, but has much greater water use efficiency than maize grain [28]. Mean water use efficiency ( $\mathrm{Mg}$ of biomass/g of water transpired) in 12 environments east of the 100th meridian was 1.9 for maize grain, 3.4 for the upland switchgrass strains and 4.3 for the lowland switchgrass strains [28]. As with rainfed maize, switchgrass yields typically increase as production fields move east from the 100th meridian.

\section{Is switchgrass difficult to establish?}

Switchgrass is not difficult to establish. However, switchgrass is slower to establish than annual grasses and cultivated cereals because stand establishment in the planting year requires energy to be directed to root and crown development for perennial growth, which intensifies aboveground competition with annual weeds [6]. Additionally, switchgrass seed lots can have a significant amount of dormant seed, which will not germinate under normally suitable conditions [6]. Since switchgrass is a $\mathrm{C}_{4}$ grass, germination and seedling growth are reduced at soil temperatures less than $20^{\circ} \mathrm{C}$ [6]. Mitchell et al. reported a regimen that produced a harvestable yield after a killing frost in the planting year if precipitation is adequate [102]. The guidelines are to:

- Develop a good seedbed (no-till seed into soybean stubble or clean till and pack to leave a faint footprint);

- Plant within 3 weeks either side of optimum maize planting date;

- Use high-quality certified seed of adapted material;

- Plant at least 300 pure live seed (PLS) $\mathrm{m}^{-2} 0.6-1.2 \mathrm{~cm}$ deep;

- Manage weeds with a pre-emergent application of $1.1 \mathrm{~kg} \mathrm{ha}^{-1}$ of atrazine [Aatrex $4 \mathrm{~L}^{\circledR} ; 6$-chloro- $N$-ethyl$N^{\prime}$-(1-methylethyl)-1,3,5-triazine-2,4-diamine] plus $560 \mathrm{~g} \mathrm{ha}^{-1}$ of quinclorac (Paramount ${ }^{\circledR} ; 3,7-$ dichloro-8quinolinecarboxylic acid); then mow or spray broadleaf weeds with 2.31 ha ${ }^{-1}$ of 2,4-D (2,4-dichlorophenoxyacteic acid) in summer [13,102]. 
Using pre- and post-emergent herbicides reduces the time required to establishment and maximum biomass yields [6]. Using a planter that controls planting depth reduces stand failure risks [102].

\section{Are specific herbicides necessary for rapid} switchgrass establishment?

Although switchgrass can be established successfully using a number of herbicide regimens, some are superior to others. For example, quinclorac is one of the few herbicides labeled for establishing switchgrass for bioenergy. Applying quinclorac in the establishment year reduced production costs compared with other herbicides and returned US $\$ 308 \mathrm{ha}^{-1}$ on a $\$ 50 \mathrm{ha}^{-1}$ investment [12]. In a multilocation study in Nebraska, South Dakota and North Dakota, a pre-emergent application of $560 \mathrm{~g} \mathrm{ha}^{-1}$ of quinclorac plus $1.1 \mathrm{~kg} \mathrm{ha}^{-1}$ of atrazine reduced weed pressure during establishment and resulted in the best switchgrass stands [13].

How much biomass will switchgrass produce in the seeding year, the first year after seeding \& when the stands are mature?

Switchgrass growth in the establishment year depends on soil moisture and temperature, fertility, and competition from weeds $[6,13,102]$. In the establishment year, switchgrass directs plant resources to develop an extensive root system, so aboveground growth is slow relative to annual grasses [6]. It is feasible to produce $50 \%$ of the yield potential of the cultivar to be available for harvest after a killing frost in the planting year, and produce and harvest $75-100 \%$ of the yield potential of the cultivar in the first full growing season after planting [6,102]. For upland cultivars, harvestable yields of $4-5 \mathrm{Mg}^{-1}$ after a killing frost are typical during the planting year using the previously mentioned herbicide regime if precipitation is near the long-term average [13,102]. In the first year after seeding, it is common for fields to produce $75-100 \%$ of potential yield, producing $8-13 \mathrm{Mg} \mathrm{ha}^{-1}$ on a dry matter (DM) basis [13,102]. By the second full production year, the stand is mature and at $100 \%$ of potential production. One 24-ha field of 'Shawnee' switchgrass, a forage-type upland cultivar, in eastern Nebraska averaged more than $9 \mathrm{Mg} \mathrm{ha}^{-1}$ for the seeding year and first two production years. The lowland switchgrass cultivars such as 'Kanlow' and 'Alamo' originated in southern latitudes and are typically adapted to areas south of $40^{\circ} \mathrm{N}$ latitude [6]. Consequently, they have not been evaluated as thoroughly at the field scale in the Great Plains and Midwest, but small plot trials of Alamo, Kanlow and three experimental lowland strains in eastern Nebraska produced an average of $10.1 \mathrm{Mg} \mathrm{ha}^{-1}$ in the year after seeding, with Kanlow producing $11.7 \mathrm{Mg} \mathrm{ha}^{-1}$ in the year after seeding [13]. Additionally, lowland strains that survive winter in the Great Plains and Midwest have been developed and are promising for biomass production in more northern latitudes. At the field scale, limited research experience indicates that the new lowland bioenergy cultivars will have greater yield potential but similar proportional yields in the seeding year and first full production year as the upland cultivars.

\section{When should switchgrass be harvested for bioenergy?}

Maximizing DM yield is the primary objective when harvesting switchgrass for bioenergy. A single harvest at anthesis or after a killing frost at a $10-\mathrm{cm}$ stubble height is typically recommended to optimize switchgrass biomass and maintain stands $[5,14,23]$. Biomass increases up to anthesis, after which biomass yield has been reported to decrease by $10-20 \%$ until killed by frost [14]. Optimum yields were attained with a single harvest during anthesis with yield ranging from 10.5 to 12.6 $\mathrm{Mg} \mathrm{ha}^{-1} \mathrm{yr}^{-1}$, and quality stands were maintained [14]. A single annual harvest optimizes efficiency in the Great Plains and Midwest, but harvest timing needs to be considered for stand maintenance, optimizing biofuel output and fitting into the farming operation. Delaying harvest until after frost may improve feedstock quality for thermochemical conversion. Two harvests provide greater biomass yields than one harvest in locations with long growing seasons, but the extra fossil fuels required to conduct two harvests may not warrant a two-harvest management system $[14,25,29]$. However, energy use may be offset by custom harvesters who need to maximize equipment use and biomass. Mulkey et al. recommended harvesting once after a killing frost to maintain stands and optimize biomass production [25]. Dormant season harvests after a killing frost ensure stand productivity and persistence, especially during drought, and allow switchgrass plants to mobilize $\mathrm{N}$ and other nutrients into roots for use the following spring [6]. Consequently, harvesting after a killing frost reduces the amount of $\mathrm{N}$ removed from the system, which reduces subsequent $\mathrm{N}$ fertilizer requirements by approximately a third and positively influences the life cycle assessment [5]. Additionally, harvesting after a killing frost and maintaining good soil fertility reduces weed problems and promotes stand longevity by promoting vigorous, competitive stands. However, delaying harvest over the winter into early spring decreased switchgrass yields by almost $40 \%$ [21]. With proper management, productive stands can be harvested for biomass annually for more than 10 years [102].

\section{How will switchgrass be harvested \& stored?}

Harvesting and baling switchgrass with commercially available haying equipment is feasible [102]. However, 
as higher-yielding bioenergy types are commercialized, specialized harvesting equipment may be required to handle the anticipated $22.4 \mathrm{Mg} \mathrm{ha}^{-1}$ yields [7]. Selfpropelled rotary head harvesters (disc mowers) are most effective for harvesting switchgrass fields with greater than $13 \mathrm{Mg} \mathrm{DM} \mathrm{ha}{ }^{-1}$ [102]. Switchgrass grown for bioenergy may need to be stored for 12 months or more since biorefineries operate 365 days a year and biomass can lose weight and quality if improperly stored [6]. Bale storage will likely be decentralized, either on farm or at a collection facility, to reduce risk of fire and minimize on-site storage at the biorefinery. Round bales tend to have less storage losses than large rectangular bales when stored outside, but rectangular bales tend to be easier to handle and can fully load trucks for transport without road-width restrictions. Along with greater handling ease, rectangular bales have greater bulk density, allowing greater truck loading weights. The average bulk density for switchgrass round bales harvested at anthesis was $167 \mathrm{~kg} \mathrm{~m}^{-3}$, whereas bulk density for round bales harvested after a killing frost was $141 \mathrm{~kg} \mathrm{~m}^{-3}$. The average bulk density for rectangular bales harvested at anthesis was $192 \mathrm{~kg} \mathrm{~m}^{-3}$, whereas bulk density for rectangular bales harvested after a killing frost was $152 \mathrm{~kg} \mathrm{~m}^{-3}$ and bulk density for chopped material harvested after killing frost was $98 \mathrm{~kg} \mathrm{~m}^{-3}$. Poor switchgrass storage conditions can result in storage losses of $25 \%$ in 12 months [102]. Switchgrass round bales stored inside for 6 or 12 months had $0-2 \%$ DM losses, whereas bales stored outside lost $5-13 \%$ of the original bale weight [30]. Losses during storage will be greater in mesic environments and reduced in drier environments. In addition to storage losses in weight, there can be significant reductions in biomass quality and the biomass may not be of acceptable quality for a biorefinery. Switchgrass bales stored unprotected outside lost up to $11 \%$ of ethanol extractables due to spoilage, which could significantly reduce conversion to ethanol [31]. Switchgrass bales need to be covered and protected during storage. Enclosed buildings provide the most expensive storage environment, but minimize storage losses and ensure the greatest feedstock value [103].

\section{Can switchgrass be produced at a cost that makes bioenergy economically feasible?}

Yes, but most studies on the economic feasibility of using switchgrass as an energy crop were based on results from small plots and extrapolated to the field scale [32,33]. However, some of the best available production cost information comes from a recent large, regional fieldscale trial in the Great Plains, USA [12]. The study was conducted on farmer fields on ten farms in Nebraska, South Dakota and North Dakota, over 5 years, and the cost of production for switchgrass to the farm gate averaged $\$ 66 \mathrm{Mg}^{-1}$ [12]. Five farmers delivered switchgrass to the farm gate at an average cost of $\$ 52 \mathrm{Mg}^{-1}$ over the 5 -year period. If stands were projected to 10 years of production, costs were reduced to $\$ 46 \mathrm{Mg}^{-1}$. The 5 -year average cost for farmers with experience growing switchgrass was $\$ 39 \mathrm{Mg}^{-1}$, and one producer grew switchgrass for $\$ 34 \mathrm{Mg}^{-1}$. They concluded that, with experience, farmers could achieve switchgrass production costs of $\$ 40-55 \mathrm{Mg}^{-1}$. Assuming a conversion rate of $0.329 \mathrm{l}$ of ethanol per kg of switchgrass, the farmgate feedstock cost would range from $\$ 0.12$ to $\$ 0.16 \mathrm{l}^{-1}$ [12]. These costs include land costs, which accounted for nearly half of the production costs, and these vary significantly from region to region so production costs will be regionally biased [6]. This research from 50 production environments demonstrates that if economical cellulosic ethanol-conversion technology is developed, switchgrass will be an economically viable biofuel crop [6]. Additionally, Bransby et al. developed an interactive budget model for planning switchgrass production and delivering switchgrass to the biorefinery, which can be used to project annual production input costs [34].

Is switchgrass grown for bioenergy net energy positive?

Growing switchgrass on marginally productive land is net energy positive. The Energy and Resources Group (University of California, Berkely, CA, USA) Biofuel Analysis Meta-Model energy model predicted switchgrass could produce greater than $700 \%$ more output than input energy [35]. However, only one study to date has used field production and input information to model the net energy value (NEV), net energy yield (NEY) and the ratio of the biofuel output to petroleum input (petroleum energy ratio [PER]) for switchgrass $[6,18]$. Schmer $e t$ al. evaluated the energy efficiency and sustainability of ethanol produced from switchgrass using NEV, NEY and PER by validating the Energy and Resources Group Biofuel Analysis Meta-Model with actual inputs from switchgrass fields from 50 production environments in Nebraska, South Dakota and North Dakota [18]. This study used an estimated conversion rate of 0.381 ethanol kg-1 biomass. Switchgrass produced $540 \%$ more renewable energy (NEV) than nonrenewable energy consumed over a 5 -year period [18]. The estimated on-farm NEY for switchgrass was $60 \mathrm{GJ} \mathrm{ha}^{-1} \mathrm{y}^{-1}$ and switchgrass produced an estimated average of $13.1 \mathrm{MJ}$ of ethanol for every MJ of petroleum input (PER). Average GHG emissions from switchgrass-based ethanol were 94\% lower than estimated GHG emissions for gasoline [18]. Previous models overestimated the energy inputs for switchgrass production by as much as two times. This study demonstrated that switchgrass is net energy positive using NEV, NEY and PER to measure bioenergy 
efficiency. This study used cultivars developed for use in pastures, so improved biomass cultivars and improved management practices should result in improvements in NEV, NEY and PER [6].

\section{How does switchgrass ethanol production} compare with no-till maize on marginal sites?

The potential ethanol yield of switchgrass averaged $34741 \mathrm{ha}^{-1}$ and was equal to or greater than the potential ethanol yield of no-till maize grain and stover on a marginally productive rainfed site in eastern Nebraska [36]. In this 5-year study, removing $50 \%$ of the maize stover each year for cellulosic ethanol reduced maize grain yield, stover yield and total biomass yield the following year. Ethanol from maize feedstock costs were $\$ 0.13 \mathrm{l}^{-1}$ at a maize price of $\$ 80 \mathrm{Mg}^{-1}$, or $\$ 0.26 \mathrm{l}^{-1}$ at a maize price of $\$ 160 \mathrm{Mg}^{-1}$ during 2006 and 2007 in the USA and compared closely to the $\$ 0.12-0.161^{-1}$ reported for switchgrass [12].

Since few studies have compared the ethanol yield of switchgrass and no-till maize directly on marginal sites, comparing regional yield data for switchgrass and maize has value, but some assumptions are required. The first assumption is that marginal land can be identified as cropland that has average annual maize yield, that is, more than $25 \%$ below the average rainfed maize production for the county (see the section 'what is marginal land?'). The second assumption is that realistic estimates are used for ethanol yield for maize grain $\left(0.521 \mathrm{~kg}^{-1}\right)$, maize stover $\left(0.3341 \mathrm{~kg}^{-1}\right)$ and switchgrass $\left(0.3341 \mathrm{~kg}^{-1}\right)$. The third assumption is that the maize harvest index for marginal land is 0.5 , with half of the total biomass produced as grain and half as stover [37]. The final assumption is that $50 \%$ of the stover can be sustainably removed from the field for ethanol production and still satisfy the residue needs for conservation and soil health. The 2010 rainfed average maize grain yield in Saunders County, Nebraska, was $7660 \mathrm{~kg} \mathrm{ha}^{-1}$ [104], minus the $25 \%$ yield reduction for marginal land, resulting in a marginal land adjusted grain yield of $5745 \mathrm{~kg} \mathrm{ha}^{-1}$ with $2873 \mathrm{~kg} \mathrm{ha}^{-1}$ of stover available for removal, for a total ethanol yield of $39501 \mathrm{ha}^{-1}$ (2990 1 ha' from grain plus $9601 \mathrm{ha}^{-1}$ from stover). Switchgrass yields in Saunders County Nebraska ranged from 11.2 to $16.8 \mathrm{DM} \mathrm{Mg} \mathrm{ha}^{-1}$, with potential ethanol yields of 3740-5620 $1 \mathrm{ha}^{-1}$ [Mrtchell R, Unpublished Data]. Consequently, ethanol production from switchgrass can be at least equal to that for maize grain and stover, which is consistent with Varvel et al. [36], and has the potential to exceed ethanol production from maize by nearly $50 \%$ on marginally productive cropland. Additionally, using the county-wide maize grain yield average of $7660 \mathrm{~kg} \mathrm{ha}^{-1}$ would produce $5260 \mathrm{l}$ ethanol ha ${ }^{-1}$ (3980 from grain and 1280 from stover), which is still less than the highest yielding switchgrass strains. The bottom line is that potential ethanol production from switchgrass on marginal land can be competitive with, and in some cases $50 \%$ greater than, maize grown on marginally productive cropland. The efficiency and cost-effectiveness of the conversion process for switchgrass and maize stover is the missing piece of the puzzle.

What is the near-term biomass improvement potential for switchgrass using conventional breeding?

Most switchgrass cultivars released to date have been developed using population improvement breeding systems, which have increased yield performance by 20-30\% from existing parent types [2]. Yield trials near Mead, Nebraska, from 2003 to 2005, indicate new material developed specifically for biomass provides a $2.2 \mathrm{Mg} \mathrm{ha}^{-1}$ yield increase. However, the most significant increases in biomass will occur with the release of switchgrass hybrids. Recent research indicates hybrid switchgrass can increase yield by $32-54 \%$ compared with parental lines [7]. It will likely require $5-10$ years to develop field-scale production systems for hybrid switchgrass, but the result will be potential harvestable yields of greater than $20 \mathrm{Mg} \mathrm{ha}^{-1}$ in the Great Plains and Midwest [7,38].

\section{Is production system information available \&} verified to facilitate sustainable production?

All practices for establishment, management and delivery to the biorefinery gate have been developed for producing switchgrass for biofuels, with research in numerous US agroecoregions detailing specific management requirements for local conditions $[39,40,102]$. Production and agronomic information including germplasm selection, establishment, weed management, fertility, harvest and storage have been developed and verified at the field scale [102]. Switchgrass has been seeded on millions of hectares of CRP grasslands since 1986, so switchgrass is not only sustainable but familiar to many producers. Switchgrass response to fertility, especially N, exemplifies the management research conducted in numerous environments and production scenarios. Switchgrass tolerates low-fertility conditions in native stands and conservation plantings, but responds to fertilizer when grown for bioenergy [41,42]. Fertilizing with $\mathrm{N}$ increases biomass yield, but recommended $\mathrm{N}$ fertilizes rates vary based on precipitation, cultivar and harvest management $[14,24,29]$. To optimize biomass, apply $10-12 \mathrm{~kg}$ of $\mathrm{N} \mathrm{ha}^{-1}$ for each DM Mg ha ${ }^{-1}$ of biomass yield if harvested at flowering [14]. At fertility rates above this level, $\mathrm{N}$ accumulated in the soil profile [14]. Fertilizer rates should be based on soil tests and potential yield [102]. Harvesting a switchgrass field at flowering that produces $11 \mathrm{Mg} \mathrm{ha}^{-1}$ of 


\section{Key term}

Foundation seed: Seed produced directly from breeder seed that is handled using standards established by the certifying agency to maintain the genetic purity and identity of the variety. Seed grown in foundation seed fields is used to grow seed for certified seed-production fields. biomass with a $1.2 \% \mathrm{~N}$ concentration removes approximately $130 \mathrm{~kg}$ of $\mathrm{N} \mathrm{ha}^{-1}$; whereas, harvesting after a killing frost may remove only half of that amount because as plants senesce biomass $\mathrm{N}$ decreases due to translocation to roots and crowns [5]. If switchgrass is harvested after a killing frost, biomass will be $80-90 \%$ of that at flowering but $\mathrm{N}$ fertilization requirements will be $30-40 \%$ lower due to remobilization out of plant material during senescence [6].

\section{Where will switchgrass fit on the agricultural} landscape?

An important aspect of feedstock supply is having enough land available to grow the required feedstock. Switchgrass is well suited to marginally productive or difficult to farm parcels (i.e., small, irregular shaped or rough) and it fits well into most farming operations. Given the size of current row crop machinery, smaller fields are becoming more difficult to farm. One viable scenario with an available land base is growing switchgrass in the corners of circular center pivot irrigation systems, which provide a large number of acres for switchgrass production. A center pivot located on a quarter section ( $\sim 64$ ha, 160 acres) typically irrigates only 53 ha (132 acres), leaving 11 ha (28 acres) of rainfed cropland in the four corners. Consequently, the pivot corners are marginally productive relative to the irrigated land because they receive no supplemental water. For example, the Upper Big Blue Natural Resource District (Figure 1) is a 740,575-ha watershed in eastern Nebraska that is heavily irrigated with center pivots and has approximately $68 \%$ of the watershed included within a $40-\mathrm{km}$ radius of an existing starch-based ethanol facility. This watershed could grow 50,500 ha of switchgrass in pivot corners alone, enough for one 189.3 million 1 (50 million gallon) per year ethanol plant at 11.2 $\mathrm{Mg} \mathrm{ha}^{-1}$ (5 tons acre-1), or two 189.3 million l per year plants at $22.4 \mathrm{Mg} \mathrm{ha}^{-1}\left(10\right.$ tons acre $\left.{ }^{-1}\right)$. Additionally, the Upper Big Blue Natural Resource District has four existing maize ethanol plants to which cellulosic ethanol plants could be co-located to take advantage of existing infrastructure.

Managing switchgrass as a hay crop is not foreign to

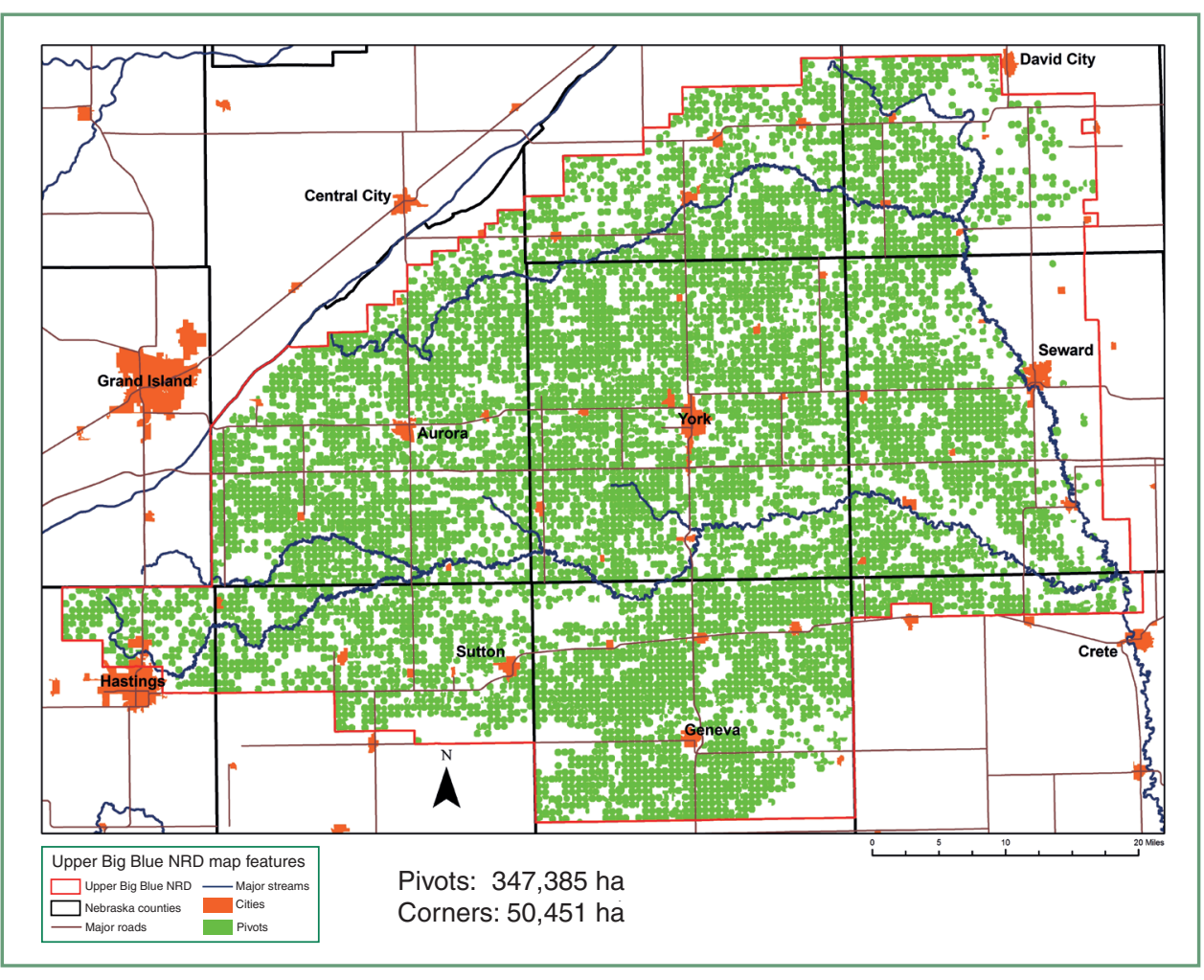

Figure 1. Map of the Upper Big Blue Natural Resource District. This is an intensively farmed watershed in eastern Nebraska that has the potential to produce enough switchgrass in the non-irrigated corners of center pivot irrigation systems to supply $100 \%$ of the feedstock for a 189.3 million I/year cellulosic ethanol facility.

NRD: Natural Resource District. most producers and the economic opportunities presented by switchgrass for small, difficult to farm or poorly productive fields will provide an economic incentive for many farmers to grow switchgrass. Additionally, given the concentration of switchgrass production around the biorefinery, cooperatives eventually may be developed to facilitate growers to pool resources to reduce risk and optimize income.

\section{What is marginal land?}

There are numerous ways to define marginal land based on environmental (i.e., slope and erodibility) or economic (i.e., productivity and size) parameters. From a bioenergy perspective, we believe marginally productive land is best defined by its economic parameters, since the environmental parameters often dictate the economics. In a long-term study in Saunders County Nebraska, dryland maize was grown on a site that qualified for the CRP. During the first seven production years, the maize yield on this site was $28.2 \%$ below the average dryland maize yield in the county. We believe a 
good working definition for marginally productive cropland for the western Corn Belt is sites that are more than $25 \%$ below the average dryland maize production for the county. Using this definition, pivot corners will be considered marginally productive in most crop production years. However, in years with high corn prices and adequate precipitation, this land is profitable. Farmers and landowners will make the decision if marginally productive cropland is best-suited to the production of perennial fuelcrops such as switchgrass.

\section{How much land is required to meet $100 \%$ of} the annual biorefinery feedstock demand with switchgrass?

Feedstock demand by a biorefinery is determined by capacity and conversion efficiency of the biorefinery, as well as the production and conversion potential of the feedstock. Biorefinery capacity is determined by economic factors and conversion efficiency is determined by the process and available technology. Currently, approximately 3341 of ethanol can be produced from each Mg of switchgrass DM using simultaneous saccharification and fermentation, with a theoretical potential of $450 \mathrm{l}$ of ethanol per $\mathrm{Mg}$ [8]. At $334 \mathrm{l}$ of ethanol per $\mathrm{Mg}$, a 189.3 million 1 (50 million gallon) per year biorefinery requires $567,000 \mathrm{Mg}$ of feedstock each year [5]. Numerous variables affect feedstock productivity, but switchgrass will produce $11-22.4 \mathrm{Mg} \mathrm{DM} \mathrm{ha}^{-1}$ in rainfed conditions in the central Great Plains and Midwest USA if fertility and precipitation are adequate [7]. The currently accepted, economically feasible maximum feedstock transport distance is $40 \mathrm{~km}$, so a $40-\mathrm{km}$ radius around a cellulosic ethanol facility contains 502,655 ha and would ensure that most of the feedstock within that radius would be transported less than $40 \mathrm{~km}$ [5,102]. Consequently, the total land area required in rainfed switchgrass production can range from 5 to $50 \%$ of the cropland in the $40-\mathrm{km}$ radius around the ethanol plant, depending on the biomass potential of the feedstock (Table 1). It is easy to understand how increasing switchgrass DM yield to the $22.4 \mathrm{Mg} \mathrm{ha}^{-1}$ goal will improve the feasibility of growing switchgrass in a region, as well as reducing the land area removed from traditional agricultural crop production and reduce the competition for feed and fuel.

How much switchgrass must be grown above \& beyond biorefinery requirements to ensure an adequate feedstock supply given the potential for drought \& DM loss during storage?

Biorefineries will need $115-120 \%$ of anticipated biomass production to ensure a continuous feedstock supply and account for yield variation due to drought and feedstock losses during storage. Yield data from 8 years
Table 1. Land required to grow feedstock to meet the annual demand for a $\mathbf{1 8 9 . 3}$ million I/year cellulosic ethanol plant within a $40-\mathrm{km}$ radius of the bioenergy facility assuming 334 I of ethanol per Mg of switchgrass.

\begin{tabular}{|rrr|}
\hline $\begin{array}{r}\text { Feedstock yield } \\
\left(\mathbf{M g ~ h a}^{-1}\right)\end{array}$ & $\begin{array}{r}\text { Hectares required to produce } \\
\mathbf{5 6 7 , 0 0 0} \text { dry matter } \mathbf{M g} / \text { year }\end{array}$ & Land area (\%) \\
\hline 2.24 & 253,125 & 50 \\
\hline 4.48 & 126,563 & 25 \\
\hline 6.72 & 84,375 & 17 \\
\hline 8.96 & 63,281 & 12 \\
\hline 11.2 & 50,625 & 10 \\
\hline 16.8 & 33,750 & 6.7 \\
\hline 22.4 & 25,313 & 5 \\
\hline
\end{tabular}

of an on-going, long-term unpublished switchgrass production study in Nebraska indicate that date of harvest plays a role in the annual variation in DM yield [Mitchell R, Vogel KB, Unpublished Data]. Harvesting switchgrass at anthesis ( $\sim 1$ August) resulted in the DM yield between years varying by $26.5 \%$ of the mean, whereas harvesting after a killing frost (early November) resulted in the DM yield between years varying by only $10.1 \%$ of the 8-year mean. Additionally, there was no significant difference in DM yield for the two harvest dates, which is contrary to previous research [14]. Consequently, it appears harvesting switchgrass after a killing frost in the central Great Plains reduces DM yield variation by more than $250 \%$ without affecting total DM yield.

Switchgrass storage losses can be $25 \%$ of total DM in 12 months for twine-tied large round bales stored outside and uncovered. However, net-wrapped large round bales stored inside or outside and covered lost less than $5 \%$ of total DM. Consequently, proper handling and storage of switchgrass bales has a significant impact on DM losses, and 5\% DM loss during storage and handling is a realistic estimate.

\section{How soon can perennial feedstocks such as} switchgrass be supplied to the biorefinery?

Full-scale switchgrass production could occur in as little as 2 years if currently-available cultivars are used, or in 4-5 years if newly developed cultivars are used. Switchgrass will produce seed during the establishment year under optimum conditions [6]. For example, a 10-ha irrigated field of switchgrass foundation seed in eastern Nebraska produces 560-1120 kg PLS ha-1 (Table 2). In turn, this foundation seed will be planted at $2.2 \mathrm{~kg}$ PLS ha-1 to grow certified seed in rows that can produce 560-1120 kg PLS ha-1 per year. This certified seed will then be planted as biomass-production fields at $4.4 \mathrm{~kg}$ PLS ha-1 ${ }^{-1}$ Consequently, each ha of foundation seed can plant 250-500 ha of certified seed-production fields that, in turn, will grow enough seed per hectare to plant 


\begin{tabular}{|c|c|c|c|c|c|}
\hline Operation & Year 1 & Year 2 & Year 3 & Year 4 & Year 5 \\
\hline Harvest foundation seed & $\begin{array}{l}560-1120 \mathrm{~kg} \\
\text { PLS ha-1 }\end{array}$ & $\begin{array}{l}560-1120 \mathrm{~kg} \\
\text { PLS ha-1 }\end{array}$ & $\begin{array}{l}560-1120 \mathrm{~kg} \\
\text { PLS ha-1 }\end{array}$ & $\begin{array}{l}560-1120 \mathrm{~kg} \\
\text { PLS ha-1 }\end{array}$ & $\begin{array}{l}560-1120 \mathrm{~kg} \\
\text { PLS ha-1 }\end{array}$ \\
\hline Plant certified seed & & $2.2 \mathrm{~kg} \mathrm{PLS} \mathrm{ha}^{-1}$ & & & \\
\hline Harvest certified seed & & & $\begin{array}{l}560-1120 \mathrm{~kg} \\
\text { PLS ha-1 }\end{array}$ & $\begin{array}{l}560-1120 \mathrm{~kg} \\
\text { PLS ha-1 }\end{array}$ & $\begin{array}{l}560-1120 \mathrm{~kg} \\
\text { PLS ha-1 }\end{array}$ \\
\hline Plant biomass fields & & & & $4.4 \mathrm{~kg} \mathrm{PLS} \mathrm{ha}^{-1}$ & \\
\hline Harvest biomass fields & & & & 4.5 $\mathrm{Mg} \mathrm{ha}^{-1}$ & $9 \mathrm{Mg} \mathrm{ha}^{-1}$ \\
\hline Biorefinery & & & $\begin{array}{l}\text { Begin } \\
\text { construction }\end{array}$ & $\begin{array}{l}\text { Finish } \\
\text { construction }\end{array}$ & Full production \\
\hline
\end{tabular}

125-250 ha of biomass per year. This single 10-ha field can grow enough seed in Year 1 to plant 2500-5000 ha of certified seed in Year 2, which will produce enough seed in Year 3 to plant 318,000-1.3 million ha of switchgrass for biomass in Year 4.

\section{Can adequate biomass be produced $\&$ delivered} to the biorefinery in a timely manner?

Using the above seed production timeline, adequate biomass can be produced and delivered to the biorefinery in as little as $4-5$ years from the time foundation seed is available, to as little as 2 years if certified seed is available (Table 3). Based on US Department of AgricultureAgricultural Research Service research, Shawnee switchgrass grown at the field scale can produce approximately $4.5 \mathrm{Mg} \mathrm{ha}^{-1}$ of biomass in the seeding year (Year 4 in Table 2) and $9 \mathrm{Mg} \mathrm{ha}^{-1}$ of biomass in the first full production year (Year 5 in Table 2). By the second full production year, up to $13.5 \mathrm{Mg} \mathrm{ha}^{-1}$ of biomass can be produced. Consequently, planting 25,000 ha of switchgrass in two consecutive years, beginning with the year prior to biorefinery construction, will produce enough biomass to operate a 189.3 million 1 cellulosic ethanol

Table 3. Large-scale switchgrass production can supply $100 \%$ of feedstock if certified seed is available for planting when the 18-24-month process of biorefinery construction begins, providing feedstock carryover to meet harvest, storage and transport losses through Year 4.

\begin{tabular}{|c|c|c|c|c|}
\hline Feedstock practice or response & Year 1 & Year 2 & Year 3 & Year 4 \\
\hline Plant biomass fields (ha) & 25,000 & 25,000 & 0 & 0 \\
\hline Total hectares & 25,000 & 50,000 & 50,000 & 50,000 \\
\hline Average yield $\left(\mathrm{Mg} \mathrm{ha}^{-1}\right)^{\dagger}$ & 4.5 & 6.8 & 11.3 & 13.5 \\
\hline Feedstock produced (Mg) & 112,500 & 337,500 & 562,500 & 675,000 \\
\hline $\begin{array}{l}\text { Biorefinery feedstock demand } \\
\text { (Mg/year) }\end{array}$ & 0 & 284,000 & 567,000 & 567,000 \\
\hline Feedstock carryover (Mg) & 112,500 & 53,500 & -4500 & 108,000 \\
\hline
\end{tabular}

Will producers grow switchgrass for the

biorefinery market?

Producers will grow switchgrass for the biorefinery market for both economic and non-economic reasons, with economic reasons having primary importance.

Net economic return per unit of land must be comparable to growing maize or soybean in the region with minimized risks. Some noneconomic reasons would include that switchgrass production fits into the farming operation, land use plans and conservation plans, or that the contract with the biorefinery supplies management and production equipment, which limits the need for farmer involvement in the production process.

There will be two types of producers of perennial bioenergy 
feedstocks. One type will be landowners who actively farm and will want to be involved in all aspects of the production process. The other type will be landowners who desire limited involvement (i.e., absentee) in the production process. Regardless of producer involvement, the feedstock production system must be sustainable and profitable for the landowner. For the involved producer, bioenergy production systems must mesh with their current crop-production systems. A cultural change from producing annual crops that provide production flexibility to perennial bioenergy crops that demand a longterm commitment will require an economic incentive for producers and a stable agricultural policy. The impediments to producer participation are economic uncertainty, the current opportunities to respond to market fluctuations provided by annual row crops, managing risk in bioenergy crops and market availability. Involved producers may be willing to sign long-term (5-10 year) bioenergy production contracts, especially on marginally productive or small fields, whereas limited involvement (i.e., absentee) landowners may be willing to include larger fields in the contract.

Farming is a business and must be profitable. Consequently, producers are most interested in net return per unit of land. The competing opportunity costs for rainfed marginal cropland in the central Great Plains and Midwest have been the CRP with rental rates of approximately $\$ 186 \mathrm{ha}^{-1}$ and cash rent with rental rates of approximately $\$ 372 \mathrm{ha}^{-1}$. Both CRP and cashrenting cropland require limited input from the landowner, so these payments become the benchmark for contract rates. Consequently, for feedstock production to be attractive to limited-involvement producers, feedstock contracts must limit producer inputs and the value must exceed CRP and cash rent by at least the tax rate $\left(\sim \$ 50 \mathrm{ha}^{-1}\right)$ for the central Great Plains.

The market for switchgrass is not limited to bioenergy production. Switchgrass is a fair-to-good quality hay source for cattle if harvested at anthesis [5]. The profit potential of growing switchgrass for bioenergy must be competitive with the grass hay market. Unless producers are under contract and compensated appropriately to deliver switchgrass for bioenergy, the hay market will compete for switchgrass. Switchgrass production, harvest and land costs will be near $\$ 66 \mathrm{Mg}^{-1}$ to the farm gate [12] and transportation and storage costs will be near $\$ 28 \mathrm{Mg}^{-1}$ [103]. Build the plants, provide an economic incentive for farmers and feedstock will be supplied.

\section{Who will bear the risk for producing bioenergy}

\section{feedstocks?}

The division of risk will depend on the conditions of the contract. It will likely be shared by the producers and the biorefinery and there is the potential for having government programs sharing some of the risk, which already occurs with federal crop insurance programs for specific crops. Currently in the USA, the Biomass Crop Assistance Program (BCAP) is a type of government risk program for perennial bioenergy crops that likely will be fully utilized by biorefineries and biomass producers based on their participation in other government programs.

One cash rent scenario is that a biorefinery will develop long-term contracts with producers on a per unit land basis, will make all management decisions, and will incur all production costs to control quality and variation within the production process. The contract rates would be similar to the cash rental rate for rainfed cropland in the region, such as $\$ 370 \mathrm{ha}^{-1}$ for 5 years in the central Great Plains. The biorefinery will determine cultivars, establishment protocols and bear all risk during the life of the contract. The biorefinery will either establish the stand or pay seeding contractors for establishment. The biorefinery would coordinate all harvesting and field processing, and organize storage and feedstock delivery. The landowner would have no input into management decisions and the biorefinery would retain ownership of the carbon credits for the duration of the contract, and provide a contract buyout clause for the producer. This scenario is similar to most cash rental contracts, would be very familiar to farmers and minimizes landowner risk, but the contract duration may be a negative. Using the data from [12] and a yield estimate of $11.2 \mathrm{Mg} \mathrm{ha}^{-1}$ (5 US tons acre $\left.^{-1}\right)$, feedstock cost for the biorefinery to the farm gate would be $\$ 66 \mathrm{Mg}^{-1} \mathrm{DM}$ plus $\$ 28 \mathrm{Mg}^{-1}$ for feedstock storage and transportation to the biorefinery [103], for a final delivered cost of $\$ 94 \mathrm{Mg}^{-1}$. Under programs such as BCAP, the biorefinery may be eligible for establishment cost share payments as well as a per ton payment for delivered feedstock. In another scenario, the biorefinery develops long-term contracts with producers on a land area basis, but more risk is shared with the producer. The contract rates would be similar to the cash rental rate for rainfed cropland in the region, such as $\$ 370 \mathrm{ha}^{-1}$ for 5 years in the central Great Plains. The biorefinery will determine acceptable cultivars and establishment protocols that must be followed for the contract, but the farmer will be responsible for establishing the stand. The switchgrass fields will be planted at the same time that biorefinery construction begins and be evaluated at the end of the growing season in the planting year to certify that a successful stand is established. The feedstock harvested after a killing frost in the establishment year will help moderate risk for the biorefinery by having feedstock in storage prior to the biorefinery becoming operational. The biorefinery would coordinate all harvesting and field processing, and establish a timeframe for feedstock delivery, such as within $72 \mathrm{~h}$ of the feedstock 
request, but harvesting and transportation to the biorefinery is the responsibility of the farmer. Another likely option is that a third-party vendor will provide delivery from the farm gate to the biorefinery or to a satellite storage facility where the biomass may be preprocessed. The contract with the biorefinery would require farmers to deliver a fixed tonnage, but farmers would receive an additional payment for deliveries exceeding the minimum to provide a production incentive for the farmer. The biorefinery would retain ownership of the carbon credits for the duration of the contract, and provide a contract buyout clause for the producer. In this scenario, the risk for the producer is not only in the lost opportunity revenue for growing annual row crops such as maize or soybean, as well as committing land to switchgrass production for the length of the contract, but also in the cost of establishment and production of quality stands, as well as harvest, storage and transport costs. As in the first scenario, using the Perrin et al. [12] economic data and a yield estimate of $11.2 \mathrm{Mg} \mathrm{ha}^{-1}$, feedstock cost for the producer to the farm gate would be $\$ 66 \mathrm{Mg}^{-1}$ plus $\$ 28 \mathrm{Mg}^{-1}$ for feedstock storage and transportation to the biorefinery [103], for a final delivered cost of $\$ 94 \mathrm{Mg}^{-1}$. Under the current BCAP program, the farmer would be eligible for establishment cost share payments as well as per ton matching funds for delivered feedstock. In addition to the $\$ 370 \mathrm{ha}^{-1}$ cash rent contract, the farmer may receive an additional feedstock production incentive from the biorefinery for exceeding minimum production levels, which ensures a feedstock supply for the biorefinery. Government incentive programs could assist farmers, farmer cooperatives and bioenergy facilities in the early stages of the industry development by ensuring establishment and profitable production for farmers and sufficient feedstock supply for the biorefineries.

\section{What ecosystem services can switchgrass provide?}

The perennial root system of switchgrass provides two important ecosystem services; protecting soil from wind and water erosion by stabilizing fragile soils, and sequestering $\mathrm{C}$ in the soil profile [43]. Soil $\mathrm{C}$ increased at a rate of $1.01 \mathrm{~kg} \mathrm{C} \mathrm{m}^{-2} \mathrm{yr}^{-1}$ in switchgrass plantings in the northern Great Plains [44]. Growing switchgrass on land formerly in annual crop production rapidly increases soil organic carbon (SOC). Switchgrass grown in North Dakota stored $12 \mathrm{Mg} \mathrm{ha}^{-1}$ more SOC in the 30-90-cm depth than cropland in a paired field experiment, indicating switchgrass stores SOC not just near the soil surface, but deeper in the soil where $\mathrm{C}$ is less susceptible to mineralization and loss [43]. In just 5 years, switchgrass grown on marginally productive cropland at three Nebraska sites resulted in an average SOC increase of $2.9 \mathrm{Mg} \mathrm{C} \mathrm{ha}^{-1} \mathrm{yr}^{-1}$ in the top $1.2 \mathrm{~m}$ of soil [16]. In South Dakota, switchgrass grown in former cropland enrolled in CRP stored SOC at a rate of 2.4-4.0 Mg ha-1 $\mathrm{yr}^{-1}$ at the $0-90 \mathrm{~cm}$ depth [45].

Growing switchgrass also affected other soil properties. In ten fields in Nebraska, North Dakota and South Dakota switchgrass changed soil bulk density (SBD), $\mathrm{pH}$, soil $\mathrm{P}$ and equivalent mass SOC [46]. Changes in SBD occurred in the surface $(0-5 \mathrm{~cm})$, with SBD increasing at the Nebraska sites, while SBD at most North and South Dakota sites declined. Soil pH changed slightly at five of the ten locations in the $0-5-\mathrm{cm}$ soil depth. Available P was measure only in the North Dakota and South Dakota sites and declined in the top $30 \mathrm{~cm}$ by $1.5 \mathrm{~kg} \mathrm{P} \mathrm{ha}^{-1} \mathrm{yr}^{-1}$ when averaged across all sites. Averaged across locations, equivalent mass SOC increased by 0.5 and $2.4 \mathrm{Mg} \mathrm{C} \mathrm{ha}^{-1} \mathrm{yr}^{-1}$ for the 2500 and $10,000 \mathrm{Mg} \mathrm{ha}^{-1}$ soil masses, respectively. These results underscore how switchgrass can affect soil property changes, though considerable variation in soil properties exists within and across locations.

Average GHG emissions from switchgrass-based ethanol were $94 \%$ lower than estimated GHG emissions from gasoline in a 5-year study conducted on ten farms in Nebraska, South Dakota and North Dakota [18]. In addition to reducing GHG emissions and increasing soil C, growing switchgrass increases landscape-scale diversity, improves wildlife habitat and diversifies farming operations, and may increase farm revenues and return marginal farmland to production [47-50]. Not harvesting some switchgrass each year would increase the habitat value for grassland bird species that require tall, dense vegetation structure [49].

What are the potential difficulties associated with growing switchgrass for bioenergy?

Producing switchgrass in large-scale monocultures does pose some potential difficulties, but most are speculation at this point [5]. The proliferation of potential disease and insect pests associated with the production of millions of hectares of switchgrass is a real concern. It is likely that the historic long-term exposure of switchgrass to pathogens native to North America and the initial pathogen screening conducted during cultivar development will limit the negative impacts of native pests [5]. However, little research has been conducted in these areas and most pathogens cannot be fully realized until switchgrass is planted at the landscape scale.

\section{Future perspective}

We have addressed many of the important questions concerning the feasibility of growing switchgrass for biofuel production in the Great Plains and Midwest. Switchgrass is an excellent feedstock for biofuel production for the Great Plains and Midwest, but is not a one-size-fits-all bioenergy feedstock. Switchgrass fits well with either the 
biochemical (ethanol; [8]) or thermochemical (bio-oil; [51]) platform. Although a sustainable ethanol production system works well with existing automobiles, has consumer acceptance, is renewable and reduces dependence on fossil fuels, the thermochemical processes require less feedstock specificity and may better handle the inherent variability in composition and lack of uniformity in a feedstock like switchgrass. However, near infrared reflectance technology provides a method for rapidly evaluating the feedstock characteristics of switchgrass such as sugar content and composition, which may help moderate the feedstock variability at the biorefinery [52]. The research to date fully supports that switchgrass for bioenergy is productive, protective of the environment and profitable for the farmer. As the USA moves forward with expanding the renewable bioeconomy, the characteristics and research history of switchgrass make it well suited to large-scale feedstock production in many agroecoregions of the USA.

\begin{abstract}
Acknowledgements
The authors thank the Rainwater Basin Joint Venture scientists

$A$ Bishop and R Grosse for providing watershed data.
\end{abstract}

Financial \& competing interests disclosure

This article is a joint publication of the US Department of Agriculture (USDA)-Agricultural Research Service and the Agricultural Research Division of the University of Nebraska. Mention of trade names or commercial products in this publication is solely for the purpose of providing specific information and does not imply recommendation or endorsement by the USDA. The USDA is an equal opportunity provider and employer. The authors have no other relevant affliations or financial involvement with any organization or entity with a financial interest in or financial conflict with the subject matter or materials discussed in the manuscript apart from those disclosed.

No writing assistance was utilized in the production of this manuscript.

\section{Executive summary}

- All management practices for establishment, management and delivery to the biorefinery gate have been developed for switchgrass for biofuels, with research in numerous US agroecoregions detailing specific management requirements for local conditions.

- Lack of adoption is likely due to lower than needed efficiencies for conversion technologies, farmers not wanting to plant switchgrass without a viable bioenergy market, and biorefineries not wanting to build without a viable long-term feedstock supply already in place.

- Switchgrass will be productive anywhere rainfed maize is productive, especially east of the 100th Meridian, and will be productive on sites not sustainably productive for maize.

- Switchgrass for bioenergy is net energy positive and average GHG emissions from switchgrass-based ethanol were $94 \%$ lower than estimated GHG emissions for gasoline.

- The potential ethanol yield of switchgrass was equal to or greater than the potential ethanol yield of no-till maize grain and stover on a marginally productive rainfed site.

- Depending on yield and conversion efficiency, growing switchgrass on approximately $10 \%$ of the land area around a cellulosic ethanol facility can meet $100 \%$ of the biorefinery feedstock demand.

- The research to date fully supports that switchgrass for bioenergy is productive, protective of the environment and profitable for the farmer.

- As the USA moves forward with expanding the renewable bioeconomy, the characteristics and research history of switchgrass make it well suited to large-scale feedstock production in many agroecoregions of the USA.

\section{References}

Papers of special note have been highlighted as:

- of interest

-. of considerable interest

1 Vogel KP. Switchgrass. In: Warm-Season $\left(C_{4}\right)$ Grasses. Moser LE, Sollenberger L, Burson B (Eds). ASA-CSSA-SSSA Monograph No. 45, Madison, WI, USA, 561-588 (2004).

2 McLaughlin SB, Kszos LA. Development of switchgrass (Panicum virgatum) as a bioenergy feedstock in the United States. Biomass Bioenergy 28, 515-535 (2005).

3 Parrish DJ, Fike JH. The biology and agronomy of switchgrass for biofuels. Crit. Rev. Plant Sci. 24, 423-459 (2005).

4 Sanderson MA, Adler PR, Boateng AA, Casler MD, Sarath G. Switchgrass as a biofuels feedstock in the USA. Can. J. Plant Sci. 86, 1315-1325 (2006).

5 Mitchell RB, Vogel KP, Sarath G. Managing and enhancing switchgrass as a bioenergy feedstock. Biofuels Bioproducts Biorefining 2, 530-539 (2008).

6 Vogel KP, Sarath G, Saathoff A, Mitchell R. Switchgrass. In: Energy Crops. Halford N, Karp A (Eds). The Royal Society of Chemistry, Cambridge, UK, 341-380 (2011).

- Recent and thorough review of all aspects of switchgrass for bioenergy.

7 Vogel KP, Mitchell RB. Heterosis in switchgrass: biomass yield in swards. Crop Sci. 48, 2159-2164 (2008).

8 Dien B, Jung HG, Vogel KP et al. Chemical composition and response to dilute-acid pretreatment and enzymatic saccharification of alfalfa, reed canarygrass and switchgrass. Biomass Bioenergy 30, 880-891 (2006).

9 Vogel KP. Seeding rates for establishing big bluestem and switchgrass with preemergence atrazine applications. Agron. J. 79, 509-512 (1987).

10 Vogel KP, Masters RA. Frequency grid: a simple tool for measuring grassland establishment. J. Range Manage. 54, 653-655 (2001).

11 Schmer MR, Vogel KP, Mitchell RB, Moser LE, Eskridge KM, Perrin RK. Establishment stand thresholds for switchgrass grown as a bioenergy crop. Crop Sci. 46, 157-161 (2006).

12 Perrin RK, Vogel KP, Schmer MR, Mitchell RB. Farm-scale production cost of 
switchgrass for biomass. BioEnergy Res. 1, 91-97 (2008).

- Most thorough economic evaluation of switchgrass managed at the field scale for bioenergy.

13 Mitchell RB, Vogel KP, Berdahl J, Masters R. Herbicides for establishing switchgrass in the central and northern Great Plains. Bioenergy Res. 3, 321-327 (2010).

- Recent research documenting herbicides for establishing switchgrass for bioenergy. Research supported the labeling of quinclorac for establishing switchgrass for bioenergy.

14 Vogel KP, Brejda JJ, Walters DT, Buxton DR. Switchgrass biomass production in the Midwest USA: harvest and nitrogen management. Agron. J. 94, 413-420 (2002).

15 Schmer MR, Mitchell RB, Vogel KP, Schacht WB, Marx DB. Spatial and temporal effects on switchgrass stands and yield in the Great Plains. Bioenergy Res. 3, 159-171 (2010).

16 Liebig MA, Vogel KP, Schmer MR, Mitchell $\mathrm{RB}$. Soil carbon storage by switchgrass grown for bioenergy. Bioenergy Res. 1, 215-222 (2008).

17 Mitchell RB, Wallace L, Wilhelm W, Varvel G, Wienhold B. Grasslands, Rangelands and Agricultural Systems. Biofuels and Sustainability Reports. Ecological Society of America, Washington, DC, USA (2010).

18 Schmer MR, Vogel KP, Mitchell RB, Perrin RK. Net energy of cellulosic ethanol from switchgrass. Proc. Natl Acad. Sci. 105, 464-469 (2008).

-. Only energetic evaluation of switchgrass managed at the field scale for bioenergy using actual on-farm inputs from nearly 50 production environments.

19 Schaeffer S, Baxendale F, Heng-Moss T et al. Characterization of the arthropod community associated with switchgrass (Poales:Poaceae) in Nebraska. J. Kansas Entomol. Soc. doi:10.2317/JKES100329.1 (2011) (Epub ahead of print).

20 Stubbendieck JL, Hatch SL, Butterfield CH. North American Range Plants (5th Edition). University of Nebraska Press, Lincoln, NE, USA (1997).

21 Adler PR, Sanderson MA, Boateng A, Weimer P, Jung H. Biomass yield and biofuel quality of switchgrass harvested in fall and spring. Agron. J. 98, 1518-1525 (2006).

- Unique approach to managing switchgrass for bioenergy, including documentation of resulting biofuel quality.
22 Ma Z, Wood CW, Bransby DI. Impact of row spacing, nitrogen rate, and time on carbon partitioning of switchgrass. Biomass Bioenergy 20, 413-419 (2001).

23 Sanderson MA, Reed R. Ocumpaugh WR et al. Switchgrass cultivars and germplasm for biomass feedstock production in Texas. Bioresource Technol. 67, 209-219 (1999).

24 Heggenstaller AH, Moore KJ, Liebman M, Anex RP. Nitrogen influences biomass and nutrient partitioning by perennial, warmseason grasses. Agron. J. 101, 1363-1371 (2009).

25 Mulkey VR, Owens VN, Lee DK. Management of switchgrass-dominated Conservation Reserve Program lands for biomass production in South Dakota. Crop Sci. 46, 712-720 (2006).

26 Casler MD, Vogel KP, Taliaferro CM et al. Latitudinal and longitudinal adaptation of switchgrass populations. Crop Sci. 47, 2249-2260 (2007)

27 Monti A, Venturi P, Elbersen HW. Evaluation of the establishment of lowland and upland switchgrass (Panicum virgatum L.) varieties under different tillage and seedbed conditions in northern Italy. Soil Tillage Res. 63, 75-83 (2001).

28 Kiniry JR, Lynd LR, Greene N, Johnson MVV, Casler MD, Laser MS. Biofuels and water use. In: New Research on Biofuels. Wright JH, Evans DA (Eds). Nova Science Publishers, Hauppauge, NY, USA, 136 (2008).

- Thorough evaluation of the water use by different biofuel feedstocks.

29 Haque M, Epplin FM, Taliaferro CM. Nitrogen and harvest frequency effect on yield and cost for four perennial grasses. Agron. J. 101, 1463-1469 (2009).

30 Sanderson MA, Egg RP, Wiselogel AE. Biomass losses during harvest and storage of switchgrass. Biomass Bioenergy 12, 107-114 (1997).

31 Wiselogel AE, Agblevor FA, Johnson DK, Deutch S, Fennell J, Sanderson M. Compositional changes during storage of large round switchgrass bales. Bioresour. Technol. 56, 103-109 (1996).

32 Vadas PA, Barnett KH, Undersander DJ. Economics and energy of ethanol production from alfalfa, corn, and switchgrass in the upper Midwest, USA. BioEnergy Res. 1, 44-55 (2008).

33 Khanna M, Dhungana B, Clifton-Brown J. Costs of producing miscanthus and switchgrass for bioenergy in Illinois. Biomass Bioenergy 32, 482-493 (2008).
34 Bransby DI, Smith HA, Taylor CR, Duffy PA. Switchgrass budget model: an interactive budget model for producing and delivering switchgrass to a bioprocessing plant. Ind. Biotech. 1, 122-125 (2005).

35 Farrell AE, Plevin RJ, Turner BT, Jones AD, O'Hare M, Kammen DM. Ethanol can contribute to energy and environmental goals. Science 311, 506-508 (2006).

36 Varvel GE, Vogel KP, Mitchell RB, Follett RN, Kimble JM. Comparison of corn and switchgrass on marginal soils for bioenergy. Biomass Bioenergy 32, 18-21 (2008).

37 Karlen DL, Varvel GE, Johnson JMF et al. Monitoring soil quality to assess the sustainability of harvesting corn stover. Agron. J. 103, 288-295 (2010).

38 US Department of Energy. US Billion-Ton Update: Biomass Supply for a Bioenergy and Bioproducts Industry. Perlack RD, Stokes BJ (Leads), ORNL/TM-2011/224. Oak Ridge National Laboratory, Oak Ridge, TN, USA, 227 (2011)

-. Recent and thorough national evaluation of the potential biomass supply for bioenergy production in the USA.

39 Teel A, Barnhart S, Miller G. Management Guide for the Production of Switchgrass for Biomass Fuel in Southern Iowa. Iowa State University Extension Publication 1710. Iowa State University, Ames, IA, USA (2003).

40 Hancock DW. The Management and Use of Switchgrass in Georgia. University of Georgia Extension Publication B1358. University of Georgia, Athens, GA, USA (2009).

41 Rehm GW, Sorensen RC, Moline WJ. Time and rate of fertilizer application for seeded warm-season and bluegrass pastures. Yield and botanical composition. Agron. J. 68, 759-764 (1976).

42 Jung GA, Shaffer JA, Stout WL. Switchgrass and big bluestem responses to amendments on strongly acid soil. Agron. J. 80, 669-676 (1988).

43 Liebig MA, Johnson HA, Hanson JD, Frank AB. Soil carbon under switchgrass stands and cultivated cropland. Biomass Bioenergy 28, 347-354 (2005).

44 Frank AB, Berdahl JD, Hanson JD, Liebig MA, Johnson HA. Biomass and carbon partitioning in switchgrass. Crop Sci. 44, 1391-1396 (2004).

45 Lee DK, Owens VN, Doolittle JJ. Switchgrass and soil carbon sequestration response to ammonium nitrate, manure and harvest frequency on conservation reserve program land. Agron. J. 99, 462-468 (2007). 
46 Schmer MR, Liebig MA, Vogel KP, Mitchell RB. Field-scale soil property changes under switchgrass managed for bioenergy. Global Change Biol. Bioenerg. doi:10.1111/j.1757-1707.2011.01099.x (2011) (Epub ahead of print).

47 McLaughlin SB, Walsh ME. Evaluating the environmental consequences of producing herbaceous crops for bioenergy. Biomass Bioenergy 14, 317-324 (1998).

48 McLaughlin SB, de la Torre Ugarte DG, Garten CT et al. High-value renewable energy from prairie grasses. Environ. Sci. Technol. 36, 2122-2129 (2002).

49 Roth AM, Sample DW, Ribic CA, Paine L, Undersander DJ, Bartelt GA. Grassland bird response to harvesting switchgrass as a biomass energy crop. Biomass Bioenergy 28, 490-498 (2005).
50 Sanderson MA, Reed R, McLaughlin S et al. Switchgrass as a sustainable bioenergy crop. Biores. Technol. 56, 83-93 (1996).

51 Boateng AA, Hicks KB, Vogel KP. Pyrolysis of switchgrass (Panicum virgatum) harvested at several stages of maturity. J. Anal. Applied Pyrol. 75, 55-64 (2006).

52 Vogel KP, Dien BS, Jung HJ, Casler MD, Masterson S, Mitchell RB. Quantifying actual and theoretical biomass ethanol yields for switchgrass strains using NIRS analyses. Bioenergy Res. 4, 96-110 (2011).

\section{- Websites}

101 US EPA. Renewable Fuel Standard. www.epa.gov/otaq/fuels/renewablefuels/ index.htm

(Accessed 15 September 2011)
102 Switchgrass for Biofuel Production. www.extension.org/pages/Switchgrass_for_ Biofuel_Production

(Accessed 29 November 2011)

103 Ag Decision Maker, an agricultural economics and business website. www.extension.iastate.edu/agdm (Accessed 29 November 2011)

104 USDA's NASS Nebraska Field Office, the fact finders for Nebraska Agriculture. www.nass.usda.gov/Statistics_by_State/ Nebraska

(Accessed 15 September 2011) 